\title{
The European Union's First Support Operation on the African Continent: Darfur
}

\author{
BESENYÖ János ${ }^{1}$
}

\begin{abstract}
The Darfur Operation is much disputed, often times it is called unsuccessful. The operation started ten years ago, and in addition to other donors, the EU took an important role in the advocacy, not to mention the fact that it launched its own support operation. This was the second operation of the EU in Africa. It worked with less people than the Artemis Operation did, but it lasted for nearly three years. Although the operation had to face several challenges, it can be called effective from the perspective of the European Union and its member states. They could utilize the lessons learned from the mission related to further operations. However, several pieces of research have been made on the European Union's activity in Darfur, but the participants of the mission did not share their experiences except for one or two conferences and articles. I (the author) served for six months in the operation in 2005. After coming home, I followed the events in the area. This research is based on my subjective experiences, other peacekeeper's knowledge, archived and open sources.
\end{abstract}

Keywords: AMIS, African Union, European Union, Darfur, Arabian, African, Cease Fire Committee, EU Military Stock, observers, logistic advisors

On February, 2003, a revolution broke out in the western part of Sudan, Darfur. The insurgen- cy was led by the Sudan Liberation Movement/Army (SLM/A). The SLM/A regarded itself as the representative of the majority population in Darfur. The rebellious organisation, and its ally, the Justice and Equality Movement (JEM), took up arms against the policies of the central government. Their major problem was that the black African farmers did not receive governmental protection against the attacks of the Arabian nomadic group, the Janjaweed. The government responded with military strikes. As part of the actions against the rebellions, the government forces committed ethnic cleansing among the innocent civilian population too. The Sudanese government forces and the Janjaweed units burnt down and destroyed hundreds of villages, causing the death of thousands, banishing millions of citizens, attacking and raping thousands of women. [1] The president of Chad, whose country was affected by the conflict too, summoned the opposing parties to the negotiating table in the summer of

2003. They set a cease-fire accord, however, it only lasted till $5^{\text {th }}$ December - when the hos- tilities recrudesced. [2] Up to $30^{\text {th }}$ September, 2004, thirty-thousand people became victims of the battles, and nearly one million people lost their homes. 2000 out of the one million dis- placed people fled to the neighbouring Chad. The African Union (AU) had to face the threat that the conflict was spreading to the neighbouring countries. Therefore, they put forward the launch of a peace operation. As a result of the international pressure the government and the

1 Colonel, Ph.D., MoD, Budapest, e-mail: besenyo.janos@hm.gov.hu 
insurgent forces on $8^{\text {th }}$ April, 2004, set up a cease-fire agreement in N'djamena. The supervi- sor of the agreement was the African Union - supported by the USA, and the EU. The Afri- can Union took the role of the mediator during the peace talks. ${ }^{2}$ However, due to the USA's pressure (whose government, according to the Swedish government, labelled the events in Darfur a genocide) the United Nations requested in a resolution the African Union to advance a peacekeeping mission. As a consequence of the pressure of the international community, the Sudanese government and the political opponents accepted establishing the mission. The AU sent a unit to Darfur between $7^{\text {th }}$ and $20^{\text {th }}$ May, 2005 to estimate the possibilities of set- ting up an observation mission. [3] After getting the report from the group, the AU Security Council made a resolution on $25^{\text {th }}$ May 2005. In the resolution they put the peacekeeping operation into action, however, the Sudanese government, the rebels and the representatives of the AU reached the Addis Ababa agreement on $28^{\text {th }}$ May 2005. It established the Cease- Fire Committee and agreed on sending military observers to Darfur. So it started the work of the African Mission in Sudan (AMIS) whose budget was estimated 26,605,432 USD. [4] As this amount of money was not at the AU's disposal, they immediately addressed a letter to the EU, because the European Union was supposed to take a great part of the financing. [5] However, the EU had been supporting the work of the AU with a significant amount of mon- ey since the establishment of the African Union on $23^{\text {th }}$ June, 2005. The EU established its own operation to back up the AMIS (also known as the EU civilian-military action to support the African Union's enhanced Mission to Sudan/Darfur), which aims to hold the European support together and to coordinate the work of the observers/advisors sent to Darfur. The operation was financed by the ATHENA mechanism. [6] The evaluation of the total upkeep was 2 million Euros. ${ }^{3}$

The operation supported the AU's actions in Sudan with constabulary activities. [7] The operation was initiated at the same time when the EU leaders accredited a special repre- sentative (European Special Representative - EUSR), Pekka Haavisto ${ }^{4}$ to Darfur. He was responsible for the cooperative activity of the Union's political and operational actions; moreover, Mr. Haavisto was in charge of the co-ordination too, accordingly he controlled the actions of the mission. [8] Furthermore, he was consulting with the AU, the AMIS and the Sudanese government's leaders. Mr. Haavisto participated in the Abuja Peace Confer- ences, where he expressed the interests of the EU. The Addis Coordination Cell helped the

2 The AU was unwilling to leave room for other regional organisations to consolidate the situation in Darfur. Since the African leaders thought that the problems of the African continent can only be solved by the Africans. The AU recons Darfur its own trial-field for their peace-making and sustaining ability, therefore they showed increased sensibility toward all international intervention attempts.

3 The total is so small because the EU leaders thought that the mission will end by the end of 2005. They expected that after the enlargement of the AMIS II, it will be able to operate alone.

4 Pekka Haavisto was member of the Finnish Parliament (1987-1996), then he was the Environment Minister in the Government of Pavaoo Lipponen between 1995-1999. Later on he became a member of the Helsinki Council, a representative of the Greens, and he was a leader of several economic organisations as well (for instance World Bank). During programs of the UN, he served in a number of crises areas, for example in

the Balkans (Kosovo), he participated in the Palestinian-Israeli peace talks as a mediator. He is a member of several scientific, economic and environmental protectionist organisations. He is a professor of the Finnish University as well as he is a guest tutor in the University of Bristol, in the University of Helsinki, and in Oberammergauban as well, at the NATO Academy. He was nominated for the position of the EU's Special Representative in Darfur in 2005, and he held that position until 2007. Between 2007 and 2011 he was commissioned to different positions in Helsinki, then in 2012 he was the nominee of the Greens in the presidential elections, where he won second place. 
work of the police and the political, military work of the special representative regarding the following points:

- Daily contact with the EU member states which participate in the mission, as well as keeping in touch with the professionals of the Administrative Control and Manage- ment Centre (ACMC) which supervises the Europeans supports for the AMIS.

- Daily contact with Brussels, supplying information to the leaders of the EU, asking for intervention if necessary related to issues out of the competence of the special representative.

- Contacting the ambassador in Addis (delegated by European states), other representatives and the European military/police officers serving in the operation

- Collaboration with the supporters of the AMIS (USA, NATO, UN, etc.) to help coordinate the mission, and to avoid the duplication of certain contributions.

The EU struggled to uphold their interests not only in the political, but in the military and police areas too, hence on $18^{\text {th }}$ July, 2005, the EU Council in its resolution (2005/557/ CFSP) delegated a leading military advisor (Colonel Philippe Mendez, France) and a lead- ing police advisor (Superintendent Douglas Brand, Great Britain) into the centre of the AU, Addis Ababa. ${ }^{5}$ [9] After that the EU's military and police advisors sent their reports directly to the EU headquarters. They could request help from the EU concerning any other issue. [10]

By September, 2005, the organisation of the EU's new support operation evolved with a proper reporting system. Considering the previous experiences, it took a great part in the assistance and actuation of the AMIS II.

The new organisational structure of the European operation: [11]

- Brussels Coordination Group/EU Military Body - Operational Group of Darfur;

- EU Combined Office at the AU's command;

- EU Special Representative and its organisation body (military and police advisors);

- European advisors of the Darfur Integrated Task Force, including the groups of the Administrative Control and Management Centre/ACMC, as well as the stock of the air-bridge actuation. (Forward Based Movement Cell);

- European members of the Cease-Fire Committee;

- The European general and police advisors, served in the mission's command in Karthoum;

- European general and police advisors served in the mission's operational command (El Fasher) and in the Combined Logistic Operational Centre;

- EU military observers in Darfur, and police advisors in external sectors.

The EU took an active part in the new operation, especially in the training and equipping of the police officers sent to the AMIS II. As the African states were not able to send enough well-trained police officers to Darfur, the declared aim of the mission, which was to protect refugees, became a risk. Their protection mainly needed police constables, not only military personnel. The police had an important role in ensuring the legality, and in building up trust between the refugees and the Sudanese police, but the police component was struggling with headcount deficiency. It could hardly arrange its own functioning, not to mention the

5 The leading military position was completed by France (Colonel Philippe Mendez), Holland (Colonel Eric Burmeister) and Hungary. The Hungarian candidate Colonel Károly Nyitrai lost against the French candidate with a small difference. [9] 
tasks that were delegated to them. The police component struggled with the following prob-

lems: [12]

- There was no clear idea about the relocation of the policemen, the related plans were incomplete.

- The African states were unable to mobilise enough police officers for the mission, so the police forces were not able to reach the proper level of their functional ability.

- The police officers sent to the mission were lacking the right capabilities. They did not speak English and they were poorly trained. These deficits diminished the possible opportunities of the police component.

- The Command and Control system of the police forces had problems too. The emula- tion between the soldiers and police officers created serious problems too. It lessened not only the effectiveness of the police officers, but also the efficiency of the mission.

- The logistic system of the AU was not able to ensure the proper provision of equip- ment, lodging, and working circumstances for the police officers, who were supposed to ensure 24 hours presence in 40 refugee camps and 25 important settlements accord- ing to the mission' objectives.

These facts were highlighted by a committee in Darfur, in 2005. They made a motion to extend the number of the policemen and to improve their training. Henceforth, the EU of- fered a "supporting pocket" on $26^{\text {th }}$ May, in 2005 . In this pocket they handled the assistance of the police component accentuated, and they offered help in the following areas:

- Supporting the command system of the police component: For this the EU offered well qualified, high ranked police officers to the AMIS. They functioned as personal advi- sors of the African police leaders. Twenty-four police advisors (offered by the EU) got positions at the AMIS, and at the higher commands of the Sudanese police agencies (Addis, Khartoum, El-Fasher, and the sector commands). The EU sent the advisors for a six month-period of time. By the way, there were some people who extended the serving period more than one time. The service superior of the European policemen was the police officer delegated to the Darfur Integrated Task Force (DITF) stock.

- Participation in the training of the police staff: Generally the training of the staff was made by the EU's two mobile training groups with ten people. Another group (consist- ing of five members) trained those African policemen, who became later drill sergeants in the police component. In this way they could improve the effectiveness of the training comparatively fast.

- Giving assistance and advice how to implement a police operation efficiently. For this purpose the EU sent a high ranking police officer to the AU's command in Addis, who had both political and planning experience.

According to the previous plans, the EU planned to send 49 police officers and 3 admin- istrators to the operation. Although the EU provided all of the necessary equipment for the policemen, they expected lodging, as well as health and personal security from the AU. ${ }^{6}$ [12] In return for an allowance of course. As the mission was not able to ensure the proper equip- ment for the advisors, they used the computers and satellite phones financed by the EU. [13] These positions were difficult to fill, because the member states were not willing to send

6 But the EU leaders anticipated that the AMIS (which was struggling with a great source deficit) will be not able to assure proper logistic insurance to the EU advisors. Therefore they planned a separate budget to assure the needs. This was a right measurement in the light of the further events. [12] 
further advisors. They could fill only 22 positions till August, 2005. Therefore Pedro Serrano, the director of the police operations, asked the EU member states to fill the vacant positions with advisors from their own countries. [14]

In order to achieve the EU's aim, to send soldiers and police officers to the AMIS II, both the EU and AU leaders had to change the rules of the mission's operation documents, because of the Sudanese government organisation's demands. They just let the European advisors into the country when they were participants of the AMIS, despite the fact that the Addis Ababa Agreement (28 May, 2004) enabled the participation of non-African states and organisations too. Nevertheless, people sent by the EU constantly faced the fact, that neither the Sudanese people, nor the leaders of the mission were happy with their presence. The EU even increased the support for the AMIS, but the situation was getting worse. The leaders of the negotiations saw less and less possibilities for a political settlement. The insurgent groups divided into smaller bunches, fighting not only agents of the Sudanese Government, but against each oth- er too. The Sudanese Government and the Janjaweeds militias burned down more and more settlements, they killed people, they committed brutality and they looted. The number of the refugees multiplied. Unequivocally, it was impossible to close the conflict with military solutions. But for the measurement of the political solution the success of the AMIS was indispensable. The peacekeepers were to be able to ballast the region. In order to achieve this, the European Union's Council sent an expert group to survey the real state of the AMIS II between $16^{\text {th }}$ and $22^{\text {nd }}$ September, 2005. They analysed the logistic problems, their effects on the function of the mission and they wanted to make moves to the EU leaders about the direc- tions of further collaboration. [15] The members of the working groups met with the leaders of the AU and the AMIS, as well as the EU advisors and observers in Addis, Khartoum, and El-Fasher. Furthermore, they visited several sectors and camps. It can be said that they got a complete picture of the mission's actions and of the current state. Ambassador Kidoulaye and the head of the DITF claimed that because of the AU's political decision the mission could not fail, and they want to continue the support measures and the actuation. According to them, the exporting of the African troops cannot be suspended because of the logistical deficiencies. The member states refused to send further soldiers and the Aid Organisations demanded more and more military groups from the AMIS so that they could maintain their undisturbed humanitarian actions. According to the ambassador, there were not many logistical problems, except that there was a lack of air-fuel and the partners (for example the EU) were not able to support the mission appropriately in accordance with its needs. Other African leaders did not know that their missions struggled with logistic problems. Moreover, they were sure that everything was going well in Darfur. They emphasised the necessity of the mission's expansion too. They thought that with the help of the donors every problem could be solved. They were worried more about not getting as much financial support as they had requested. They expressed concerns about the transmission of the operation to the UN. Their main goal was to gain absolute control over the subsidies which the AU got. They noted that the EU should not set conditions according to this. Unlike them, the military supervisors of the mission admitted the problems which were threatening the functioning of the mission. Despite these dangerous factors, they talked about the necessity of continuing the operations and managing a new enlargement of the participants. In their opinion, putting a robust mil- itary force into action would be the only way to make peace in Darfur. Hence new groups, equipment (combat cars, combat helicopters, etc.) and more financial support had to be sent 
to them. The members of the group saw it unequivocally that the representatives of the AU in Addis were unable to control the operations in Darfur and to settle the maintenance of logis- tics. Respectively, the operation command did not assure the necessary information. It was obvious that the mission's command and control system's work was limited, and this was one of the reasons why the mission seemed unsuccessful. The group noted that the leaders of the AMIS did not take the advice of the experts who were sent to Darfur in March, 2005. ${ }^{7}$ [16] They were endeavouring to close the mission without a disgraceful failure. At this point an idea came up, that by the middle of 2006 the mission would be transferred to the UN. But till that time they asked for further financial help, because at this point the mission was struggling with a 40 million Euro deficit, and they expected the acquitting from the donors. According to the Europeans who were serving in Darfur, the biggest problems were related to the bad leadership, the lack of collaboration, the bad planning, the deficits (air-fuel, food, drinking water, etc.), the lack of competence, and the deterioration of the security circumstances. The members of the group reconciled with the leader of the Pacific Architects \& Engineers (PAE) (this organ arranged the supplement of the mission), who said that the mission had serious logistic problems. For instance the AMIS got only $30-51 \%$ of the total needs. For example due to the passengers who travelled with the food-delivery airplanes the amount of the food diminished and at the end it was never enough.

Besides the fuel deficit, bad organisation also worsened the provision. The PAE's leader said that the sector commanders often created financial funds, and they bought food from the funds to feed their soldiers. The leader also said that he did not see any sense in extending the number of the military groups until the proper circumstances were provided. He indicated that they did not know that European police advisors were coming, and it was very difficult to give them accommodation. This case showed appropriately the communication problems between the organs of the mission. This information was confirmed by the command of the police officers, who were very disappointed because of the accommodation they got. How- ever, the group got good news about the mission of the police component, nevertheless, of

1,560 people only 850 arrived. ${ }^{8}$ [17] Even so the police officers started to move out to the refugee camps and the safety rate ameliorated. But the communication and logistic problems further diminished the efficiency of the police officers.

The group indicated in the résumé of the account that the enlargement of the mission tack- led logistic problems, particularly the lack of fuel and food. The experts of the Joint Logistic Operation Center (JLOC) ballasted the provision system a little, ${ }^{9}[18]$ but the financial prob- lems, the unserviceable command and control system, the malignancy of the parties, the dis- sension of the different elements caused continuous problems. They counselled giving bigger competence to the JLOC managing the logistic issues and to establish the Joint Operation

7 Several advisors confirmed that they were very frustrated due to the fact that the AU asked for the EU's financial-logistic help, but they did not care about the opinion of their advisors. Several people were indignant, because the Africans did not respect the Europeans, although the EU was the greatest supporter of the AMIS. Several African officers did not know that the EU was giving assistance to them, they thought that the advisors are from Canada and America. [16]

8 The stronger actions of the police officers were the result of the commander-change. The previous police commander was in conflict with the military commander of the mission. His follower was the South-African Daniel Moenyana who was much more active than his predecessor.

9 Sadly the leaders of the mission often ignored the advice of the logistic experts. They just used the ideas of the professionals in case of emergency. That is why the leaders of the group noted in the recommendation that the AMIS leaders should use the advice of the experts. [18] 
Centre (JOC) because if the command was solid, then there would not be any emulation be- tween the components. Moreover, they considered the sustainability of the EU's support very important because it was a core factor for the functioning and the cessation of the mission and would be damaging for all participants. Colonel Michael Eger created a résumé about the health provision. The medical expert noted that the civilian company (chosen by the AMIS) had not assured the services which they offered in the contract. The medical support of the mission was defective. The peacekeepers could use the French military force hospitals located in Chad (Abechi and N'djamena), but they were 1000-2000 km far away. Most of the African troops had no medial crew, the soldiers did not get medical preparation, and there were not enough first aid kits. The lieutenant colonel also noted that the European officers serving in Addis and Khartoum got normal medical service, but the officers in El-Fasher or in the sectors did not get proper medical support. [19] This issue remained a problem till the end of the mission, partly this was one of the reasons why the European states did not want to send more advisors and observers to the staff of the AMIS. According to the report of the expert group, the EU decided to form their role in the mission in tune with three important aims: [20]

- Renewing the political agreements with active participation of the EU;

- Helping the AMIS to work more efficiently;

- Helping the AU to close the conflict quietly, so after a successful consolidation the AMIS could leave Sudan.

By then the leaders of the EU were expecting (moreover, they offered) the UN to take over the mission, but the AU refused this. The EU and other donors decided to continue the assistance for the AMIS's work despite the chaos. According to the plans this help cost 100 million Euros for the European states in 2006. Even so, the EU planned to support the medi- um-term transmission of the mission. In November, 2005, the EU Soldier Core made a report analysing the situation in Darfur. The utilization of the support and the functioning of the mission were checked. It was noted that establishing the DITF was a good idea but creating the correspondence between the operation areas was not successful, the policemen and the soldiers took part in the work of the mission in an inadequate way. The DITF leaders often contended with the command in Khartoum, and they had no exact information about the events in the area of operation. They remarked, according to Khartoum that its role and its tether are often unclear, which leads to conflicts. However, the command exercise was to maintain connections with the Sudanese governmental organisations, and to arrange the lo- gistic issues of the mission, but in the logistic area it did not engage in major activities. Ac- cording to the command in Darfur several negative facts emerged. The AMIS Command did not coordinate the work of the components, there was a strong contention between the sectors and other commands, moreover, the peacekeepers were also rivalling. The mission split into parts and it did not try to operate uniformly. It worked in accordance with the habit of the current commander. Although the JLOC did good work in the logistic area, the Joint Opera- tion Centre existed only in plans so the solid control over the mission was not achieved in

2005. According to the report, the AMIS's growth was only apparent on paper but actual positive change was not made in Darfur. In a way the report condemned the European mem- ber states too because it noted that of the 50 soldier/policeman positions they only filled 21, from which 16 positions were filled only after February, 2006. Hence the EU leadership tried to motivate the member states to take a bigger role in the support. It was asked separately to 
send a medical officer (because of the deteriorating health circumstances) to the JLOC organ- isation, to facilitate the medical support of the European advisors/observers. The countries that sent the advisors/observers saw the problems clearly, some of them did not send more advisors to the logistic system of the operation. [21] The EU's Military Staff commander Perruche indicated in his letter to the EU leaders that till the end of 2005 around 100 Europe- an advisors and observers served in the AMIS staff. [22] However, to keep up the EU's role in the mission it was necessary to deploy more military and police officers. On $24^{\text {th }}$ Novem- ber, 2005, the EU Military Staff sent a letter to the member states, in which they asked them to testify by $5^{\text {th }}$ December, how they want to support the AMIS further, and they also tried to request more observers and advisors to Darfur. But the member states did not hurry with the answer because it seemed likely that again they cannot fill 13 positions out of 16 places. Great Britain announced it would diminish the number of the advisors. Italy and Spain did not send new ones after the service time of their advisors expired. Hungary claimed to leave the mission. Yet, because of the strong commitment of the EU, it was very important to send European advisors and to ensure the functional capability of the mission. For this reason, the member states tried everything in order to improve the bad work and living conditions of the European advisors. [23] For example they gave them communication equipment, they rented houses for the officers serving in El-Fasher so that they could sleep in houses, not in tents. They tried to make their living conditions more comfortable in Darfur. ${ }^{10}$ [24] However, more and more European officers complained about the bad living conditions. [25] Moreover, the European military observers did not get their salaries from the mission, even though the AU got the money from the donors. The AU was asked a lot of times to pay the salaries, but it did not grant that, so the EU paid them from the ATHENEA Mechanism's budget. [26] It was not easy to fill the vacant positions, as the AU demanded more professionals. For example on $29^{\text {th }}$ November, 2005, it requested lawyers to Khartoum and El-Fasher in order to arrange the documents of the AMIS II's operations. [27] In 2006, during Colonel Philippe Mendez's tour of duty, the EU offered only one candidate for the vacancy: Colonel Philippe Beny, who be- came the special representative for the next 6 months. [28] This example presents how diffi- cult it was to find other European advisors. According to a report, the year 2006 was highly important for the mission, so important to the EU that it wanted to extend its role in the mission's work. A greater involvement did not come into reality, there were barely a few European observers in the camps, and the number of the European officers diminished too. ${ }^{11}$

In February, 2006, out of 31 positions only 15 were filled. 11 officers wanted to go home before March and there were no new officers to replace them. All in all these problems result- ed in the leaving of the EU, for this they created the extraction plan. [29] The EU Military Staff's analyses in 2006, provides information about 2 military observers in Chad, while in

10 The EU assumed that they pay for the air travel of the observers between El-Fasher and Khartoum from the budget of the ATHENEA Mechanism. They pay their way when they go home too, not just in the case of service. This was necessary because the AMIS launched a regular flight between the two cities (with the help of civil enterprises). The flight was not fit for the basic secure requirements. Nevertheless, all of the African soldiers and policemen used it. As they often overloaded the airplane, it was a game of hazard to use it. One of the airplanes crashed on $24^{\text {th }}$ December, 2005. No one survived the tragedy. Because of this the EU military staff prohibited to use the airplanes for the Europeans and gave them tickets for civilian airplanes free of charge. [24]

11 After the Hungarian secession several countries lowered the number of their personnel in the mission. In the beginning of 2006 , this was the footing: Cyprus (1 person), France (5 people), Great Britain (2 people), Germany (1 person), Italy (1 person), Austria (1 person), Spain (2 people), Portugal (1 person). 
Darfur none. Hence, they drew the attention of member states again to send military and police officers as soon as possible. [30] For this only Slovakia applied and sent two observ- ers. [31] In this period the members of the mission started to speak officially about the trans- mission of the operations to the world organisation. The EU supported this initiative and of- fered further support to execute it as soon as possible. On $30^{\text {th }}$ April, 2006, Brigadier General Francis Girand's duty came to an end as the vice president of the Cease-Fire Committee. The EU appointed Brigadier General Oliver Pitty to his position. In the meantime, the Peace Treaty of Darfur was signed, which ensured the EU one new position inside of the Cease-Fire Committee. Apart from the job, this officer was responsible for the observers' and advisors' financial-logistic support, the functioning of the EU ensured communication equipments. This position was very useful later, because the people who were serving in the mission often requested and received help from the Main Officer. There was a change related to the provi- sion of the officers too, as on $1^{\text {st }}$ March, 2006, the AU terminated the contract with Medical Services Support which provided medical supply to the mission. The Command of the AMIS decided that the newly arrived battalion's medical sections will ensure the primary health care in the mission. The more serious surgeries were made exclusively in the state hospital in El-Fasher. [32] However, this concept was not acceptable for the EU because of previous experience. The fact that the Nigerian battalions did not bring medical personnel to Darfur raised the question: whether the AMIS is able to ensure health care for the European advisors as well or not. [33] First, the EU Military Council planned to extract the whole European Staff by $30^{\text {th }}$ March, 2006. After the agreements the EU signed a contract with the US gov- ernment that in exchange for money the PAE takes care of the pressing medical service prob- lems for the 30 European officers. [10] In April 2006, the EU Military Council sent a medical group of two to Darfur. They proposed various recommendations after the surveys on the field, to improve the health care there. [34] For example, till there was no ensured medical service for the European observers, the EU Military Staff forbade leaving the camps, so they could not go on patrol. [35] In May, 2006 the EU sent a Swedish medical group to the prov- ince who gave advice and organised first aid courses for the African peacekeepers, taught them how to treat at least minor injuries. After that the health care problems were solved, the EU introduced new rules to ensure safer working conditions for the staff. As a result, the European staff could stay in the mission. ${ }^{12}$ [36] [47]

Yet, the attitude of the advisors turned worse, especially in Addis Ababa where the pre- vious collaboration disappeared and distrust affected the work quality negatively. [17] Not- withstanding the previous problems, the AU was very satisfied with the work of the European advisors and on $18^{\text {th }}$ May, 2006, they asked the EU to send another six advisors. Finally the Forward Joint Mission Headquarters (/FJMHQ) was established in Darfur. Both the police officers and civilians played a great role in its work. [37] On $6^{\text {th }}$ June, 2006, the EU eventually offered four staff officers for different positions. [38] However, they previously had planned to send home all of the observers. At the end they let them stay, moreover they increased their number to 32 people. [14] The member states kept on the constant observer circulation

12 Soon after this, the DITF asked the Military Staff to ensure the equipment for the AMIS to build two camp hospitals. The EU asked them to clarify in their petition what they needed. Their wishes were unduly huge. Moreover they asked for the same medicine for 2.1 million Euros from the Swedish too. The EU refused to give the supply because the UN was taking over the mission. They noted, when the AU asked for any kind of assistance it had to be constantly re-established and real - for the EU to consider their needs. [36] [47] 
(generally it worked adequately with few problems) till the cessation of the AMIS. [39] The EU tried to integrate the lessons learned by the previous observers and advisors into the train- ing of the new officers. Between $18^{\text {th }}$ and $20^{\text {th }}$ June, 2006, they organised a lessons learned conference in Brussels to which they invited everyone who had served in Darfur to date. The ones who could not receive their honours previously had the chance to obtain them during the conference. [39] The ex-observers and the advisors made motions in several topics to the EU Military Staff, and they utilized a lot from them (ensuring GPS instruments, creating a reference book about the operation, improving the standard of the training, etc.). [40] At the same time the EU sent not just soldiers and policemen to the AMIS, but civilian officials too, mainly financial, legal and logistic specialists, although they were less visible than the other group members. [41]

Colonel Francois Amelineau, the military advisor of the EU special representative noted that while the EU still gave important support for the AMIS in the beginning of 2007, there were not so many positive results, because the leaders of the mission especially the military commander - Mayor General Aprezi - ignored the advice. They demanded the financial and logistic support, but they refused the advice related to the utilization of the money because of the "African leadership". Occasionally they tried to play the donors off against each other. From the end of 2006 they gave the chance to the UN to participate in the leadership because they were preparing to give the operation to the world organisation. In February, 2007, the UN sent 47 military and 30 police advisors to Darfur to coordinate the activities related to the problems. Even so the operation struggled with logistic problems. The biggest problem was still the supplement of catering, so the AMIS tried to organise 260,000 ready-meal kits, and they expected the financing from the donors. France gave them a part of the required mon- ey. [42] The EU remained the major supporter of the mission but Brussels planned to pull out the European advisors and observers after the UN's takeover. This process was coordinated by the new special representative Torben Brylle. His predecessor (Pekka Haavisto) got an- other leading position at the UN. [43]

Between $18^{\text {th }}$ and $20^{\text {th }}$ June, 2007, the leading officer of the EU's military staff - Lieu- tenant Colonel Ronald Dorenbos - visited the operational area to find out personally what living and working conditions the European officers have. Although the lieutenant colonel got reports about the circumstances, he was shocked that the European advisors and ob- servers were living in austere conditions. Yet, they were in a good mood and they did their job suitably. But the dealing with the European officers astonished him. Albeit they gave a position to every European in the mission's staff, they were not integrated into the AMIS system, and were treated like strangers. For instance, they were not allowed to participate in the handover - discussions but they were expected to accomplish every task. [44] There were similar cases in El-Fasher, in the organisation of the JLOC. The African commander banished the European and Canadian advisors from the discussions, while he was complaining that he did not have enough people to carry out the professional duties, not to mention the organi- sation's tasks related to the handover of the mission. He notified that in positions of trust he wanted to see only African officers, and he did not care about the opinions of the "whites", because the mission was under African control. [45] Only those got bigger honour who were in logistic or financial positions, those who were indispensable for the mission. Despite all of these difficulties every European soldier tried to work well for the AMIS. On the other hand the European police integrated completely into the police component and they became indis- 
pensable for the African police. The health care was better and the health risks lowered. The European observers moved out of the rented house because an Egyptian officer who lived in the neighbourhood was killed by unknown people. Shortly the Sudanese government organs arrested three people. All of them admitted the commitment of the crime, so the Europeans moved back to the house. The lieutenant colonel noted that the three advisors in Khartoum were living in civilised living and working conditions. In his report he mentioned that while the EU and the donors were still giving important support to the AMIS, it became nearly non-functioning. They were only waiting for the takeover by the UN. [46]

Considering the report, the EU leaders supported the UN's takeover in every possible way and they continued the financial support of the AMIS. The activity of the European military and police officers slowed down, they did not undertake new conflicts for the mission. And so they were waiting for the remodelling of the operation, when the European contingent was extracted and the EU's support operation was officially eliminated.

\section{Summary}

Between 2005 and 2007, the EU gave political, military-police and financial-logistic support for the AMIS. It can be said that the EU's assistance was essential for the AU, for without their help the operation would have collapsed. Although the EU's support was financial and logistic, ${ }^{13}$ the professional work of more than 100 military and police officers (who were delegated by the EU member states) helped a lot to keep up the functioning of the mission. It was an important contribution too that the EU transported more than 2,000 African soldiers and policemen to the operational area and to their homes from its own budget. The role of the EU was understated so its merits were not recognised even if they should have been. On the other hand, it can be said that the operation was successful and the lessons learned there were utilized in further missions. ${ }^{14}$

\section{References}

[1] BESSENYÖ J.: Logistic Experiences: The case of Darfur - Promoting Peace and Security in Africa. Finnish Department of Strategic and Defence Studies, 235 (2006), 49-50.

[2] Fact Sheet: EU Response to the crisis in Darfur. Brussels, 10 June, 2004. HM-HIM HL MH Separated Assortments 78 II/AMIS - Sudanese mission.

[3] Briefing Note on the renewal of the mandate of the AU Mission in the Sudan (AMIS) - PSC/ $P R / 2(X L I I)$.

[4] PCS/AHG/Comm-27.05.2004. HM-HIM HL MH Separated Assortments 78-II/AMIS - Sudanese Mission.

[5] PSD/246/1141. HM-HIM HL MH Separated Assortments 78-II/AMIS - Sudanese mission

13 During the two and half years the EU gave over 300 million Euro to the AMIS, and the member states gave another 500 million Euros to the mission's budget.

14 The European political and military leaders learnt a lot from the experiences of the operation in Darfur. During the EU's Consultative and Supporting Operation in Congo they could use this knowledge, so the Europeans had a much more positive line there. 
[6] Council Joint Action on the European Union civilian military supporting action to the African Union mission. In the Darfur Region of Sudan. HM-HIM HLMH Separated Assortments 77/AMIS-Sudanese Mission.

[7] Council Joint Action 2005/557/CFSP of 18 July 2005 on the European Union Civilian- Military Supporting Action to the African Union Mission in the Darfur Region of Sudan. Official Journal of the European Union, L 188, 207 (2005), 46-51. www.operationspaix. net/DATA/DOCUMENT/3437 v COUNCIL_JOINT_ACTION_2005_557_CFSP_on_the_ European_Union_civilian-military_supporting_action_to_the_African_Union_mission_in_the_Darfur_region_of_Suda.pdf (downloaded: 1307 2015)

[8] Council Joint Action appointing a Special Representative of the European Union for Sudan. Brussels, 13 July, 2005. HM-HIM HL MH Separated Assortments 78-II/AMIS - Sudanese Mission.

[9] IM 07-07/04 DG 317/05. Brussels, 22 July, 2005. HM-HIM HL MH Separated Assortments 78-II/AMIS - Sudanese mission.

[10] HM-HIM HL MH Separated Assortments 77/AMIS - Sudanese mission.

[11] IM-07-07/07 CCM 024/05. HM-HIM HL MH Separated Assortments 78-II/AMIS - Sudanese mission.

[12] EU Organization Arrangements to Manage the Consolidated Package of Support to AMIS II. HM-HIM HL MH Separated Assortments 78-I/AMIS - Sudanese mission.

[13] Draft Concept for EU Civilian/Military Supporting Action to AMIS II. HM-HIM HL MH Separated Assortments 78I/AMIS - Sudanese mission.

[14] Status of EU Assistance Mission to AMIS II. and shortfall in personnel. Brussels, 18 August, 2005. HM-HIM HL MH Separated Assortments 78-II/AMIS - Sudanese Mission.

[15] Report: Council Secretariat AMIS II assessment mission 16-22 September 2005. HM-HIM HL MH Separated Assortments 78-II/AMIS - Sudanese mission.

[16] IM 07-07/03 CCM 046/06. HM-HIM HL MH Separated Assortments 78-II/AMIS - Sudanese mission.

[17] Monthly Report EUSR Sudan, April 2006. - HM-HIM HL MH Separated Assortments 78-II/ AMIS - Sudanese mission.

[18] Report: Council Secretariat AMIS assessment mission 16-22 September 2005. HM-HIM HL MH Separated Assortments 78II/AMIS - Sudanese mission.

[19] CCD 02-04-00/03 CCM 003/05. HM-HIM HL MH Separated Assortments 78-II/AMIS - Sudanese mission.

[20] Strengthening EU Action in Response to Developments in Darfur. Brussels, 30 November, 2005. HM-HIM HL MH Separated Assortments 78-II/AMIS - Sudanese mission.

[21] IM 07-07/03 DG 498/05. HM-HIM HL MH Separated Assortments 78-II/AMIS - Sudanese mission

[22] IM 07-07/03 DG 496/05. HM-HIM HL MH Separated Assortments 78-II/AMIS - Sudanese mission.

[23] IM 07-07/03 DG 510/05. HM-HIM HL MH Separated Assortments 78-II/AMIS - Sudanese mission.

[24] IM 07-07/03 DG 082/06. HM-HIM HL MH Separated Assortments 78-II/AMIS - Sudanese mission.

[25] IM 07-07/03 CCM 005/06. HM-HIM HL MH Separated Assortments 78-II/AMIS - Sudanese mission. 
BESENYŐ János: The European Union's First Support Operation on the African Continent: Darfur

[26] IM 07-07/03 DG 365/06. HM-HIM HL MH Separated Assortments 78-II/AMIS - Sudanese mission.

[27] IM 07-07/03 DG 503/05. HM-HIM HL MH Separated Assortments 78-II/AMIS - Sudanese mission.

[28] IM 07-07/03 DG 048/06. HM-HIM HL MH Separated Assortments 78-II/AMIS - Sudanese mission.

[29] IM 07-07/03 CCM 046/ IM 07-07/07 CCM 024/06. HM-HIM HL MH Separated Assortments 78-II/AMIS - Sudanese mission.

[30] IM 07-07/03 DG 070/06. HM-HIM HL MH Separated Assortments 80/AMIS - Sudanese mission

[31] Military Advice on EU Support to AMIS and Possible AMIS - UN Transition. HM-HIM HL MH Separated Assortments 78-II/AMIS - Sudanese mission.

[32] IM 07-07/03 DG 208/06. HM-HIM HL MH Separated Assortments 80/AMIS - Sudanese mission.

[33] IM 07-07/03 DG 101/06. HM-HIM HL MH Separated Assortments 80/AMIS - Sudanese mission.

[34] IM 07-07/03 DG 253/06. HM-HIM HL MH Separated Assortments 78-II/AMIS - Sudanese mission.

[35] IM 07-07/03 DG 261/06. HM-HIM HL MH Separated Assortments 78-II/AMIS - Sudanese mission.

[36] IM 07-07/03 DG 271/06. HM-HIM HL MH Separated Assortments 80/AMIS - Sudanese mission.

[37] AU request for advisors PSD/DITF/NV/1869. HM-HIM HL MH Separated Assortments 75/ AMIS - Sudanese mission.

[38] IM 07-07/03 DG 347/06. HM-HIM HL MH Separated Assortments 78-II/AMIS - Sudanese mission.

[39] IM 07-07/03 DG 196/06. HM-HIM HL MH Separated Assortments 80/AMIS - Sudanese mission.

[40] IM 07-07/03 DG 383/06. HM-HIM HL MH Separated Assortments 78-II/AMIS - Sudanese mission.

[41] EUSR MA WEEKLY REPORT - Week 06/2007. HM-HIM HL MH Separated Assortments 78-II/AMIS - Sudanese Mission.

[42] EU MSR WEEKLY REPORT - Week 04/2007. HM-HIM HL MH Separated Assortments 78-II/AMIS - Sudanese Mission.

[43] EU MSR WEEKLY REPORT - Week 21/2007. HM-HIM HL MH Separated Assortments 78-II/AMIS - Sudanese Mission.

[44] EU MSR WEEKLY REPORT - Week 23/2007. HM-HIM HL MH Separated Assortments 78-II/AMIS - Sudanese Mission.

[45] EU MSR WEEKLY REPORT - Week 26/2007. HM-HIM HL MH Separated Assortments 78-II/AMIS - Sudanese Mission.

[46] DGEUMS visit to Sudan/Darfur 18-20 June 2007. HM-HIM HL MH Separated Assortments 78-I/AMIS - Sudanese mission. 